ISSN (print): 1698-6180. ISSN (online): 1886-7995

www.ucm.es/info/estratig/journal.htm

Journal of Iberian Geology 36 (2) 2010: 165-174

doi:10.5209/rev_JIGE.2010.v36.n2.4

\title{
A Probable Neoceratopsian Manus Track from the Nanushuk Formation (Albian, Northern Alaska)
}

\author{
Probable pisada de Neoceratopsia en la Formación Nanushuk \\ (Albiense, Norte de Alaska)
}

\author{
A. R. Fiorillo ${ }^{1}$, P. L. Decker ${ }^{2}$, D. L. LePain ${ }^{3}$, M. Wartes 3 , P. J. McCarthy ${ }^{4}$ \\ ${ }^{1}$ Museum of Nature and Science, Dallas, Texas, USA, tfiorillo@natureandscience.org \\ ${ }^{2}$ Alaska Division of Oil \& Gas, Anchorage, Alaska,USA,paul.decker@alaska.gov \\ ${ }^{3}$ Alaska Division of Geological \& Geophysical Surveys, Fairbanks, Alaska, USA, david.lepain@alaska.gov; marwan. \\ wartes@alaska.gov \\ ${ }^{4}$ University of Alaska, Department of Geology and Geophysics, and Geophysical Institute, Fairbanks, Alaska, USA, \\ mccarthy@gi.alaska.edu
}

Received: 30/10/09 / Accepted: 30/06/10

\begin{abstract}
We report a likely neoceratopsian manus track from an exposure of the Nanushuk Formation along the Colville River in northern Alaska. The track described here contains the impressions of five digits, arranged as an arc, which identify this specimen as a manus. Details of the impression suggest that it is neoceratopsian rather than ankylosaurian. The length of the chord of the arc of the track is approximately $25 \mathrm{~cm}$, which is half the size of manus tracks found west of Denver, Colorado, USA attributed to the $10 \mathrm{~m}$ long Maastrichtian Triceratops.

The Nanushuk Formation is a succession of complexly intertonguing marine and nonmarine strata interpreted as shelf, deltaic, strandplain, fluvial, and alluvial overbank deposits. Deposited in the foreland basin north of the Brooks Range, the rock unit is present throughout most of the northern foothills belt and subsurface of the central and western North Slope coastal plain. Fossil and radiometric data place this outcrop within the Albian. If the identification of this track is correct, this is one of the earliest occurrences of neoceratopsians from North America. The occurrence of this track in Alaska substantiates the biogeographic model of faunal exchange between Asia and North America through a Cretaceous land bridge known as Beringia.
\end{abstract}

Keywords: Ceratopsians, Alaska, Cretaceous, Biogeography, Land Bridge, Beringia 


\section{Resumen}

Presentamos una probable huella de mano atribuida a neoceratopsido de un afloramiento de la Formación Nanushuk a lo largo del Río Colville, en el norte de Alaska. La huella descrita contiene la impresión de cinco dígitos, dispuestos en arco, que identifican este espécimen como una mano. Los detalles de la impresión sugieren que se trata de un neoceratopsido más que de un ankilosaurio. La longitud de la cuerda del arco de la huella es aproximadamente de $25 \mathrm{~cm}$, lo cual es la mitad del tamaño de las huellas de mano encontradas al oeste de Denver, Colorado, EE.UU, y atribuidas a Triceratops, un taxón de unos $10 \mathrm{~m}$ de largo de edad Maastrichtiense.

La Formación Nanushuk es una sucesión de capas de origen marino y no marino complejamente interdigitadas e interpretadas como depósitos de plataforma, deltaicos, de playas progradantes, fluviales y de overbank aluvial. Depositada en una cuenca de antepaís al norte del Brooks Range, la unidad de roca está presente a lo largo de la mayor parte de la franja septentrional de colinas, y en el subsuelo de la zona central y occidental, de la llanura costera de North Slope. Los fósiles y los datos radiométricos sitúan este afloramiento en el Albiense. Si la identificación de la huella es correcta, es una de las apariciones más tempranas de neoceratopsidos en Norteamérica. La aparición de esta huella en Alaska apoya el modelo biogeográfico de intercambio faunístico entre Asia y Norteamérica a través de un puente de tierra cretácico conocido como Beringia.

Palabras clave: Ceratopsio, Alaska, Cretácico, biogeografía, puente de tierra, Beringia

\section{Introduction}

The Cretaceous dinosaur record of Alaska has grown to become robust since the early scientific reports of the 1980s (Roehler and Stricker, 1984; Parrish et al., 1987; Brouwers et al., 1987; Davies, 1987). Whereas the latest Cretaceous part of the Prince Creek Formation of northern Alaska is the richest source of polar dinosaur remains (Rich et al., 2002), the older Cretaceous Nanushuk Formation is proving to be a rich source of fossil vertebrate material as well with an emerging record consisting largely of dinosaur tracks (Roehler and Stricker, 1984; Parrish et al., 1987; Gangloff, 1998a, b; Fiorillo, 2004, 2006).

We report here a likely neoceratopsian manus track from an exposure of the Nanushuk Formation along the Colville River in northern Alaska near the confluence of the Killik and Colville Rivers (Fig. 1). Microfossils, megafossils, and radiometric data place this outcrop within the Albian. If the identification of this track is correct then this is one of the earliest documented occurrences of neoceratopsians from North America.

Many vertebrate paleontologists studying the dinosaur faunas of Asia and North America have hypothesized the existence of a land bridge connection between these two continents (Russell, 1993; Cifelli et al., 1997; Sereno, 2000; Fiorillo, 2008), often termed Beringia or the Bering Land Bridge. This connection facilitated faunal exchange between these two continents. Detailed tectonic reconstructions (e.g. Lawver et al., 2002) have shown that plates were in place for this land bridge by approximately 120 - $110 \mathrm{Ma}$ (Fig. 2). Whereas multiple biogeographic models exist to explain the global distribution of neoceratopsians specifically (Chinnery et al., 1998; ChinneryAllgeier and Kirkland, 2010), the occurrence of this track in time and space substantiates the biogeographic model of faunal exchange between Asia and North America through Cretaceous Beringia. Further, the track suggests that neoceratopsians, regardless of the direction of dispersal, were among the first to use the land bridge.

\section{Geologic Background}

The Nanushuk Formation is present throughout the northern foothills belt and subsurface of the central and western North Slope coastal plain and the rock unit is a succession of complexly intertonguing marine and nonmarine strata interpreted as marine shelf, deltaic, strandplain, fluvial, and alluvial overbank deposits (Ahlbrandt, 1979; Huffman, 1985; Huffman et al., 1988; Mull et al., 2003; LePain et al., 2008, 2009; Wartes and Decker, 2008). The thickness of the unit ranges from $2,750 \mathrm{~m}$ in the west to a zero edge approximately $75 \mathrm{~km}$ east of Umiat and in the area of the present day Colville River delta. The present day distribution of the Nanushuk Formation is limited to the northern foothills belt and coastal plain where it consists of a lower, dominantly marine succession of intertonguing shallow-marine shale, siltstone, and sandstone, and an upper, dominantly nonmarine succession of intertonguing mudstone, sandstone, conglomerate and minor coal (Mull et al., 2003). The contact between these units is typically gradational due to interfingering. Both units grade north to east-northeast (basinward) to outer-shelf, slope, basinal shale, and minor sandstone of the upper part of the Torok Formation.

The locality that produced this specimen crops out at Killik Bend along the Colville River, and is situated in a succession of interbedded marine and nonmarine strata. The Nanushuk Formation in this region has been well studied with Huffman et al. (1981) providing the first de- 


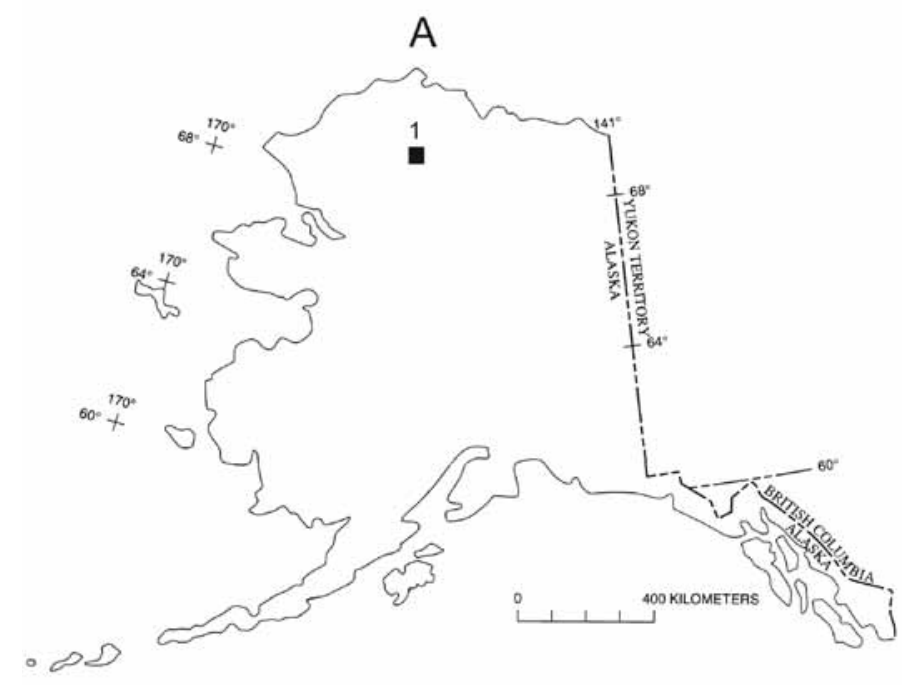

B

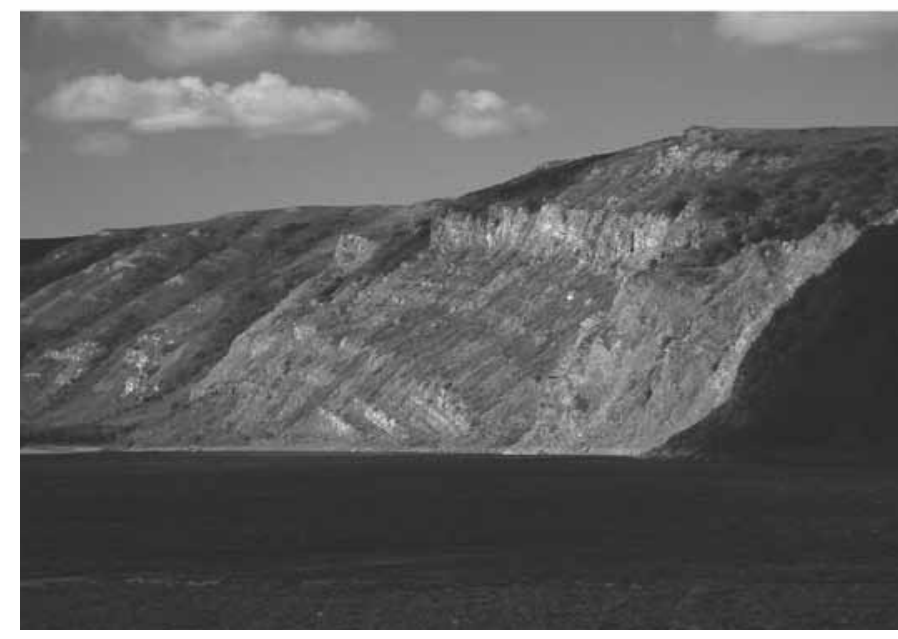

Fig. 1.- A. Generalized map showing approximate location of Killik Bend section. B. Outcrop of Nanushuk Formation along the Colville River at Killik Bend.

Fig.1.- A. Mapa general mostrando la localización aproximada de la sección Killik Bend. B. Yacimiento de la Formación Naushuk a lo largo del rió Colville en Killik Bend.

tailed sections of the area and the relatively nearby area of the Awuna River area. The Killik Bend exposure is interpreted from well and seismic data to be positioned within the lower to middle part of the Nanushuk Formation in this local area, but perhaps within the younger one-third of the time-transgressive formation in a more regional sense (LePain et al., 2008). The most recent published geologic mapping in this area stops one kilometer north of this exposure at the southern edge of the Ikpikpuk River quadrangle, where Mull et al. (2005) mapped Nanushuk rocks as the mainly nonmarine upper unit. However, they mapped exposures a few kilometers to the east as undifferentiated Nanushuk Formation, and the exact proportions of nonmarine versus marine deposits in this part of the Nanushuk deltaic complex remain poorly documented.

\subsection{Overview of depositional setting of the Killik Bend section}

The top of the Killik Bend section is in the hinge of a relatively tight syncline at the southeast end of the outcrop. This exposure contains a number of stacked, coarsening-upward parasequences that record a highfrequency oscillation between nonmarine and marginal marine coastal plain-bayfill facies and normal marine delta front and/or shoreface facies (Fig. 3). Terrestrial deposits consisting of thin coals and carbonaceous mudstones that are locally rooted and color mottled, are repetitively interbedded with marine facies. Invertebrate fossil remains from this section and nearby sections include the ammonite Pseudpulchellia flexicostata (Imlay) and pelecypods Inoceramus anglicus Woods and Arctica sp.?, as well as invertebrate traces such as Macaronichnus, Rosselia, Rhizocorallium, Gyrochorte, Planolites and possible Thalassinoides (LePain et al., 2008). These invertebrate fossils support a nearshore marine depositional setting. Teredolites-bored wood and siderite concretions suggest brackish conditions in places. Included in the Killik Bend section are several horizons containing dinosaur tracks (LePain et al., 2008; pers. obs. by ARF and PJM), most of which can be attributed to ornithopods. Gangloff (1998a) reported similar occurrences of ornithopod tracks near this section.

The vertical and lateral facies complexity at Killik Bend is consistent with deposition in a deltaic system. A preliminary interpretation of this section suggests deposition in a river-dominated delta in contrast to the more pervasive wave influence observed in deposits of the Nanushuk Formation to the east (LePain et al., 2008, 2009).

\subsection{Age Review}

The Nanushuk Formation hosts locally abundant and diverse megafossils ranging from middle Albian to Cenomanian in age (Imlay, 1961). Faunal evidence indicates that most of the formation is Albian and that only the uppermost part is Cenomanian (Mull et al., 2003). Constraints on the age of the Killik Bend outcrop considered here come from samples collected at this location as well as at the eastern and western "Horseshoe" measured sections which are located approximately $75 \mathrm{~km}$ farther upstream along the Colville River that seismic correlations 


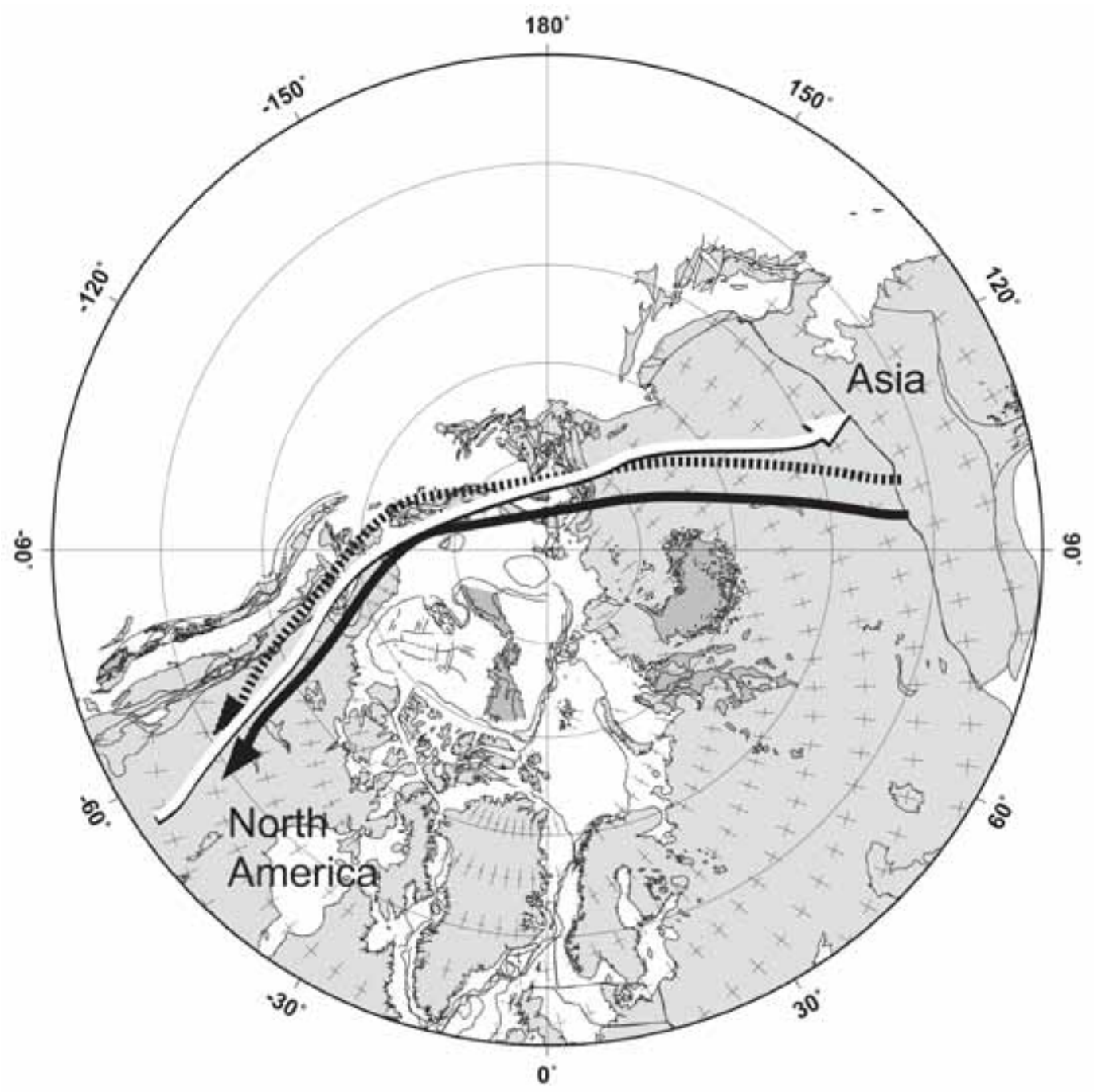

Fig. 2.- Polar projection of the paleogeography of northern Asia and northern North America at 110 Ma. Dot shows approximate position of Killik Bend 110 Ma. Base map by the PLATES Project University of Texas Institute of Geophysics. Arrows highlight faunal exchange model for marginocephalians between Asia and North America in the Cretaceous (sensu Sereno, 2000).

Fig. 2.- Proyección polar de la paleogeografía del Norte de Asia y norte de Norteamérica hace 110 m.a. El punto muestra la posición aproximada de Killik Bend hace 110 m.a. El mapa de base corresponde a las láminas Project University de Texas del Institute of Geophysics. Las fechas representan el modelo de intercambio de faunas de los marginocéfalos entre Asia y Norteamérica en el Cretácico (según Sereno, 2000).

suggest are approximately age-equivalent (LePain et al., 2008). The data summarized below from Wartes et al. (in press) include microflora (palynomorphs) and microfauna (foraminifera), marine megafossils, and U-Pb geochronology from a thin tuff bed associated with coal.

Of the ten palynomorph samples collected from the Killik Bend locality and eight from the eastern Horseshoe section, all yielded microfloral assemblages indicative of an Albian age. Foraminifera results were less consistent, with more than half the samples proving barren, one providing a Barremian age (clearly reworked), and two from Killik Bend suggesting an Aptian to early Albian age (likely reworked).

The three invertebrate marine megafossils mentioned above provide useful age constraints. The bivalve Arctica sp.? from Killik Bend was assigned an Early Cretaceous age - a broad range, but nonetheless useful in this context since it indicates the track-bearing section does not include the Cenomanian. The eastern Horseshoe section yielded Inoceramus anglicus, a bivalve interpreted to range from middle to late Albian; this species is mod- erately common in the lower Nanushuk Formation in northern Alaska and has also been reported from the Killik Bend section (Imlay, 1961). The ammonite Pseudpulchellia flexicostatata was recovered from approximately 15 meters below the I. anglicus at the eastern Horseshoe locality and was assigned a precise age of late middle Albian.

The U-Pb geochronology data are derived from laser ablation-inductively coupled mass spectrometry analyses of 30 zircon grains from a 5-10 cm-thick bentonitic tuff associated with coal at the eastern Horseshoe locality. Interpreting the precise depositional age is complicated by the presence of zircon subpopulations of varying ages. This phenomenon is increasingly recognized in zircon geochronologic studies of airfall volcanic material where some grains are clearly too old to reflect the eruptive event (xenocrysts), but there are others that are more difficult to distinguish from juvenile zircons (e.g. Bryan et al., 2008). Nevertheless, the interpreted mean age of the tuff in the Nanushuk Formation is clearly no younger than Albian. Although more refinement of these data is 
needed, current interpretation indicates a likely depositional age range of 105-108 Ma (middle Albian).

\section{Methods}

A mold of the track described here was made in the field using Smooth-On Equinox ${ }^{\mathrm{TM}} 50$ silicone putty. In the laboratory at the Museum of Nature and Science, an epoxy replica was made from the mold. This mold was then scanned and rendered to produce the contoured version of this track for figure 4. Scanning was done with NextEngine ${ }^{\mathrm{TM}}$ HD Desktop 3D scanner and ScanStudio $^{\text {TM }}$ HD PRO software. Scans were converted and rendered with Rapidform ${ }^{\circledR}$ XOR2 ${ }^{\mathrm{TM}}$ Redesign, AccuTrans $3 \mathrm{D}$ version 2.11.4, and LightWave $3 \mathrm{D}{ }^{\circledR}$ version 9.3. The contoured version of this track provided a more objective basis for comparison of this track to published accounts of various dinosaur tracks in the literature.

The impressions of the digits of the track described below form a somewhat arcuate outline. There are no satisfactory ichnological terms to describe this geometry in a vertebrate track. Therefore, we use here a linear measurement from one end point of this arc to the other as a metric for size of the track. Herein, using standard mathematical terminology, we refer to the metric as a chord.

\section{Description}

The track described here confirms a single track. This concave epirelief track came from a smooth bedding plane of limited exposure, approximately three times the size of the track. No other tracks were evident on this bedding plane.

The morphology of feet of ceratopsians and thyreophorans is very similar. In their overview of the global distribution of purported ankylosaur tracks, McCrea et al. (2001) provided details on the skeletal and footprint characters distinguishing ankylosaur tracks from ceratopsian tracks. Table 1 summarizes these key features identified by McCrea et al. (2001). The clear impression of five digits identifies this track as having been made by a manus rather than a pes (Fig. 4).

The somewhat arcuate, symmetrical distribution of these short toe impressions is consistent with the anatomy of a ceratopsid hand, such as Centrosaurus and Triceratops (McCrea et al., 2001; Fujiwara, 2009), which has longer metacarpals in digits I-III and short metacarpals in digits IV and V, and shorter toes. In contrast, in thyreophoran hands the distribution of impressions is even more arcuate with greater distances between the impressions, resulting in a star-shaped impression (e.g., McCrea

\section{Killik Bend, Colville River, Alaska}

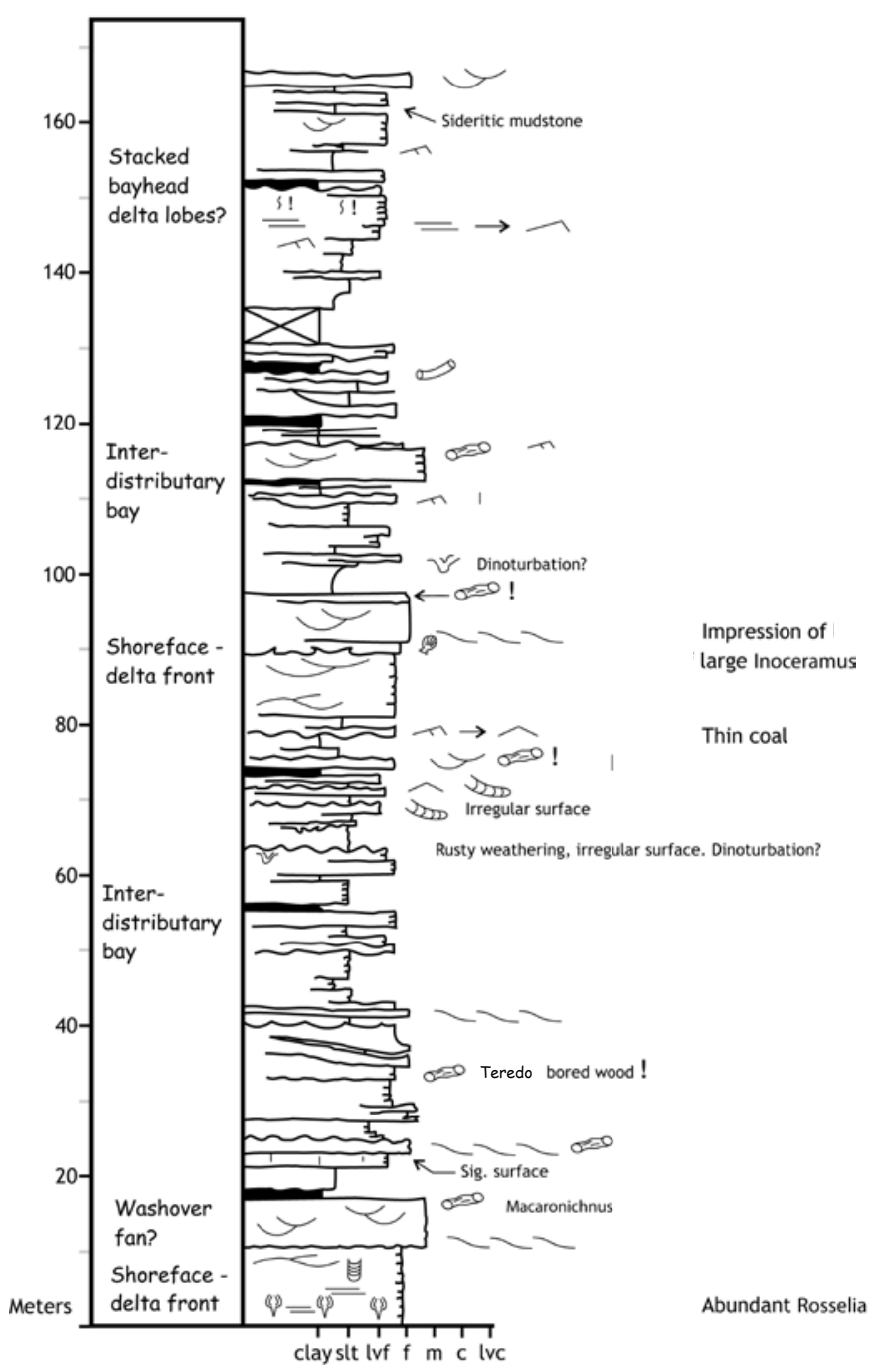

Fig. 3.- Geologic section measured at Killik Bend. Section measured by LePain, Decker and Wartes (LePain et al., 2008).

Fig. 3.- Sección geológica medida en Killik Bend. Sección medida por LePain, Decker y Wartes (LePain et al., 2008).

et al., 2001, fig. 20.1a; Lockley, 1991, fig. 5.4; Lockley and Meyer, 2000, fig. 8.15b).

Further, the digit impressions appear to taper distally (Fig. 4) with impressions for digits IV and V sequentially reduced in width. The breadth of the ungual impression left by digit III is approximately $5 \mathrm{~cm}$. Digits II and III leave the deepest and broadest impressions $(6 \mathrm{~cm}$ and 5 $\mathrm{cm}$ respectively), followed by digit I $(3.8 \mathrm{~cm})$, then digit IV $(3.5 \mathrm{~cm})$ and digit $\mathrm{V}$ which measures approximately $1.8 \mathrm{~cm}$ across. Additionally, the contoured version of the track (Fig. 4C) shows that digit I is shallow compared to digits II-V, and thus is not the most prominent impression. These are all key features in the identification of ceratopsian tracks (sensu McCrea et al., 2001). 


\begin{tabular}{|c|c|}
\hline Ceratopsian Skeletal & Ankylosaur Skeletal \\
\hline $\begin{array}{c}-4 \text { digits on pes } \\
-5 \text { digits on manus }\end{array}$ & -4 digits on pes \\
-5 digits on manus \\
- manual digits IV and V reduced & - manual digit V reduced \\
- shorter toes compared to metatarsals & - longer toes compared to metatarsals \\
\hline digits have appearance of tapering distally & Ankylosaur Footprint \\
\hline Ceratopsian Footprint & (Tetrapodosaurus ichnosp.) \\
\hline (Ceratopsipes ichnosp.) & - longer toe impressions \\
- symmetrical appearance & - Digit I most prominent \\
\hline
\end{tabular}

Table 1. List of characters that distinguish ceratopsian tracks from ankylosaur tracks. Table combines skeletal characters and footprint characters. Characters taken from McCrea et al., 2001.

Tabla 1. Lista de caracteres que permiten diferenciar las huellas de ceratopsios de las de anquilosaurios. La tabla combina caracteres esqueléticos y de las huellas. Los caracteres se han tomado de McCrea et al., 2001.

The length of the chord of the arc of the track is approximately $25 \mathrm{~cm}$, which is approximately half the size of purported ceratopsian manus tracks found west of Denver, Colorado, USA attributed to the $10 \mathrm{~m}$ long Maastrichtian Triceratops (Lockley and Hunt, 1995). This would suggest a ceratopsian or similar trackmaker approximately 4-5 meters in body length.

\section{Discussion}

Olaus Murie (1954) in his classic contribution regarding the identification of animal tracks asked the simple introductory question "What has happened here?" Anecdotally he pointed out the value and richness of the discovery of the occurrence of even single tracks in understanding who was sharing the ecosystem with him. His argument was that tracks, even isolated ones, serve as presence data.

Published accounts of tracks attributed to the Ceratopsia are typically referring tracks to the more derived Ceratopsidae (McCrea et al., 2001; Lockley, 1991; Lockley and Meyer, 2000) rather than addressing the attributes of the tracks for the broader taxonomic group. The single track described in this report compares favorably with published accounts of tracks and skeletal features for those previously published records for the more derived ceratopsians.

The size of this track is somewhat problematic however. If the relative size of this track compared to the purported tracks of Triceratops (Lockley and Hunt, 1995) is an indication of body size, then this trackmaker was $4-5 \mathrm{~m}$ in body length. This estimated body length is well within the size range for ceratopsids (sensu Dodson et al., 2004) rather than the broader group of Neoceratopsia, which comprise the Ceratopsidae plus numerous basal taxa.

Accepted Ceratopsids have a geologic range of Campanian - Maastrichtian (Dodson et al., 2004). Neoceratopsians have a geologic range of Tithonian - Maastrichtian and a body length range of $1-3 \mathrm{~m}$ (You and Dodson, 2004). Sues and Averianov (2009a) re-examined the skeletal remains of Turanoceratops from Uzbekistan and determined that this animal was a true ceratopsid. However, Farke et al. (2009) used the data provided by Sues and Averianov (2009a) and incorporated them into a larger data matrix leading them to conclude that Turanoceratops remained outside the Ceratopsidae and was in fact a sister taxon. Sues and Averianov (2009b), in their reanalysis later agreed with this subsequent interpretation. Therefore, if this is indeed a track made by a Ceratopsid, then the temporal gap between Ceratopsid body fossils and traces is very large.

Chinnery et al. (1998) attributed several isolated teeth recovered from the Cedar Mountain Formation of Utah (Albanian-Cenomanian boundary) and the Arundel Formation of Maryland (late Aptian) to neoceratopsians. These teeth, however, are of an expected size for neoceratopsians (Chinnery et al., 1998; their table 1).

Where then are the body fossils to support the interpretation of the track described here? Chinnery-Allgeier and Kirkland (2010) mention several examples of undescribed neoceratopsian skeletal specimens from Lower Cretaceous rock units in North America. And with full descriptive publication of these specimens there may be viable specific candidates for this track maker.

But it also remains that the reality of the known fossil record is that it is incomplete; a fact recognized by Charles Darwin himself who offered that a better sampled fossil record would help understand ancient biodi- 

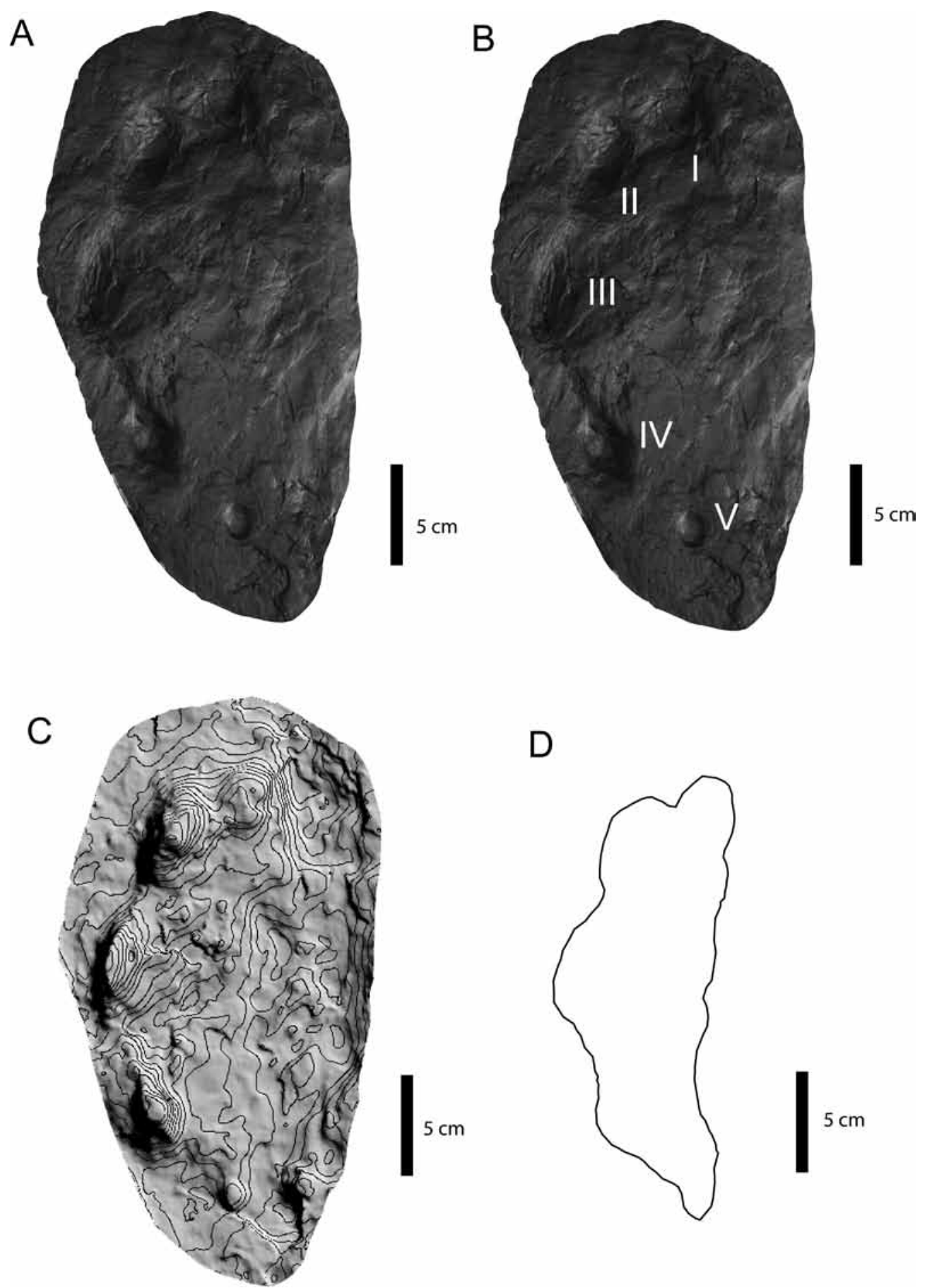

Fig. 4.- A. Photograph of epoxy replica of track from Killik Bend. B. Photograph of epoxy replica with digits I-V marked. C. Contoured image of track from Killik Bend. D. Outline of track from Killik Bend taken from contoured image.

Fig. 4.- A. Fotografía de la réplica epoxy de la huella de Killik Bend. B. Fotografía de la réplica epoxy con los dígitos I-V marcados. C. Imagen contorneada de la huella de Killik Bend. D. Silueta de la huella de Killik Bend tomada a partir de la imagen contorneada.

versity and evolutionary transitions (Dodson, 2009). The optimistic perspective then is that there are many depositional basins containing quantities of nonmarine rocks that remain to be examined. There is a vast expanse just within northern Alaska of rocks of Early Cretaceous age that have not been examined for their vertebrate paleontological potential. Further, there are similar sequences of rocks in eastern Asia that also bear scrutiny (Kirillo- 
va et al., 2000). It seems easier to envision an increase in body size within a temporally correlative taxonomic group than to invoke a significant range extension for a more derived, younger-occurring taxonomic group. We prefer a conservative approach suggesting that this track was made by a very large Neoceratopsian rather than a member of the Ceratopsid and that this track is a clue that new neoceratopsian taxa remain to be discovered within the enormous geographic area bridging Asia and North America.

With the advent of new discoveries of ceratopsians, multiple biogeographic models now exist to explain the global distribution of their skeletal remains (Chinnery et al., 1998; Chinnery-Allgeier and Kirkland, 2010). The classic model states that during the Cretaceous, Alaska served as a land bridge for faunal exchange between Asia and North America (Russell, 1993; Cifelli et al., 1997; Sereno, 2000; Fiorillo, 2008). In addition, in order to explain several new neoceratopsian skeletal discoveries in eastern North America, others have suggested that a ceratopsian dispersal event crossed what is now Europe (Chinnery et al., 1998; Chinnery-Allgeier and Kirkland, 2010), a model not mutually exclusive with the classic model.

Because tracks serve as presence data, this new footprint record, supports the classic model of a Beringian connection between Asia and North America (Russell, 1993; Cifelli et al., 1997; Sereno, 2000; Fiorillo, 2008). The occurrence in time and space is consistent with tectonic models that show a reasonable connection between the two continents by the Albian (e.g., Lawver et al., 2002). Thus, if correctly identified, this track shows that neoceratopsian dinosaurs were not only present in Cretaceous Beringia, but among the first to use the newly formed gateway between the two continents.

\section{Conclusions}

In an Albian-aged section of rock containing many dinosaur tracks, a manus attributable to a neoceratopsian was discovered within the Nanushuk Formation of northern Alaska near the confluence of the Killik and Colville Rivers. The depositional environments for Nanushuk Formation at this outcrop are dominantly coastal plainbayfill and shoreface/delta front facies from a river-dominated delta setting. The occurrence of this track in Alaska substantiates the biogeographic model of faunal exchange between Asia and North America through a Cretaceous land bridge known as Beringia. Further, the occurrence of this neoceratopsian track suggests this group of animals was among the first to use this connection.

\section{Acknowledgements}

The authors first thank the numerous various field members responsible for the successes leading to this project; particularly Drs. David B. Norton and Roland Gangloff. Our thanks to Dr. Lawrence Lawver and Lisa Gahagan and the PLATES Project, University of Texas Institute of Geophysics for the providing the base map for Figure 2. Thanks also to Thomas Adams and the Visualization Lab in the Huffington Department of Earth Sciences at Southern Methodist University for 3D scanning and rendering of the track for Figure 4C. The National Science Foundation grants OPP 0424594 (to Fiorillo) and OPP 0425636 (to McCarthy) provided financial support for research on the North Slope. We thank Drs. Christian A. Meyer, Fregenal Martinez, M., and A. D. Buscalioni for very helpful comments that improved the quality of this manuscript, though the authors take full responsibility for all interpretations provided. We also gratefully acknowledge the support of the Museum of Nature and Science, Dallas, Whole Earth Provision Company, Barrow Arctic Science Consortium, Veco Polar Resources and the Arctic Field Office of the Bureau of Land Management for additional administrative support in the field.

\section{References}

Ahlbrandt, T.S. (ed.) (1979): Preliminary geologic, petrologic, and paleontologic results of the study of Nanushuk Group rocks, North Slope, Alaska. United States Geological Survey Circular 794.

Brouwers, E.M., Clemens, W.A., Spicer, R.A., Ager, T.A., Carter, L.D., Sliter, W.V. (1987): Dinosaurs on the North Slope, Alaska: High latitude, latest Cretaceous environments. Science, 237:1608-1610. http://dx.doi.org/10.1126/science.237.4822.1608

Bryan, S.E., Ferrari, L., Reiners, P.W., Allen, C.M., Petrone, C.M., Ramos-Rosique, A., Campbell, I.H. (2008): New Insights into Crustal Contributions to Large-volume Rhyolite Generation in the Mid-Tertiary Sierra Madre Occidental Province, Mexico, Revealed by U-Pb Geochronology. Journal of Petrology, 49:4777. http://dx.doi.org/10.1093/petrology/egm070

Chinnery, B.J., Lipka, T.R., Kirkland, J.I., Parrish, J.M., BrettSurman, M.K. (1998): Neoceratopsian teeth from the Lower to middle Cretaceous of North America. In: S.J. Lucas, J.I. Kirkland, J.W. Estep (eds.). Lower and Middle Cretaceous Terrestrial Ecosystems. New Mexico Museum of Natural History and Science Bulletin 14:297-302.

Chinnery-Allgeier, B.J., Kirkland, J.I. (2010): An Update on the Paleobiogeography of Ceratopsian Dinosaurs. In: M.J. Ryan, B.J. Chinnery-Allgeier, D.A. Eberth (eds.). New Perspectives on Horned Dinosaurs. Indiana University Press, Bloomington: Pp. $387-404$.

Cifelli, R.L., Kirkland, J.I., Weil, A., Deino, A.L., Kowallis, B.J. (1997): High-precision 40Ar/39Ar geochronology and the ad- 
vent of North America's Late Cretaceous terrestrial fauna. Proceedings of the National Academy of Sciences, 94:11163-11167. http://dx.doi.org/10.1073/pnas.94.21.11163

Davies, K.L. (1987): Duck-billed dinosaurs (Hadrosauridae: Ornithischia) from the North Slope of Alaska. Journal of Paleontology, 61:198-200.

Dodson, P. (2009): Dinosaurs in the year of Darwin. The Anatomical Record, 292:1240-1245. http://dx.doi.org/10.1002/ar.20981

Dodson, P., Forster, C.A., Sampson, S.D. (2004): Ceratopsidae. In: D.B. Weishampel. P. Dodson, H. Osmólska (eds), The Dinosauria, 2nd ed. University of California Press, Berkeley: 494-513.

Farke, A.A., Sampson, S.D., Forster, C.A., Loewen, M.A. (2009): Turanoceratops tardabilis--sister taxon, but not a ceratopsid. Naturwissenschaften, 96:869-870. http://dx.doi.org/10.1007/ s00114-009-0543-8

Fiorillo, A.R. (2004): The dinosaurs of arctic Alaska. Scientific American, 291(6):84-91. http://dx.doi.org/10.1038/scientificamerican1204-84

Fiorillo, A.R. (2006): Review of the Dinosaur Record of Alaska with comments regarding Korean Dinosaurs as comparable high-latitude fossil faunas. Journal of Paleontological Society of Korea, 22:15-27.

Fiorillo, A.R. (2008): Cretaceous dinosaurs of Alaska: Implications for the origins of Beringia. In: R.B. Blodgett, G. Stanley (eds.), The Terrane Puzzle: new perspectives on paleontology and stratigraphy from the North American Cordillera. Geological Society of America Special Paper 442: 313-326. http:// dx.doi.org/10.1130/2008.442(15)

Fujiwara, S.-I. (2009): A reevaluation of the manus structure in Triceratops (Ceratopsia: Ceratopsidae). Journal of Vertebrate Paleontology, 29:1136-1147. http://dx.doi. org/10.1671/039.029.0406

Gangloff, R. A. (1998a): Arctic dinosaurs with emphasis on the Cretaceous record of Alaska and the Eurasian-North American connection. In: S.G. Lucas, J.I. Kirkland, J. W. Estep (eds.), Lower and Middle Cretaceous Terrestrial Ecosystems. New Mexico Museum of Natural History and Science Bulletin 14: 211-220.

Gangloff, R.A. (1998b): Newly discovered dinosaur trackways from the Cretaceous Chandler Formation, National Petroleum Reserve-Alaska. Journal of Vertebrate Paleontology, 18 (supplement to 3):45A.

Huffman, A.C., Jr. (ed.) (1985): Geology of the Nanushuk Group and related rocks, North Slope, Alaska. United States Geological Survey Bulletin 1614.

Huffman, A.C., Jr., Ahlbrandt, T.S., and Bartsch-Winkler, S., (1988): Sedimentology of the Nanushuk Group, North Slope. In: Gryc, G. (ed.), Geology and exploration of the National Petroleum Reserve in Alaska, 1974 to 1982. United States Geological Survey Professional Paper 1399: 281-298.

Huffman, A.C., Jr., Ahlbrandt, T.S., Pasternack, I., Stricker, G.D., Bartsch-Winkler, S., Fox, J.E., May, F.E., Scott, R.A.Y. (1981): Measured sections of the Cretaceous Nanushuk and Colville Groups undivided, central North Slope, Alaska. United States Geological Survey Open-File Report 81-177.

Imlay, R.W. (1961): Characteristic Lower Cretaceous megafossils from northern Alaska. United States Geological Survey Professional Paper 335.

Kirillova, G.L., Markevitch, V.S., Belyi, V.F. (2000): Cretaceous environmental changes of East Russia. In: H. Okada, N.J. Mateer, (eds.), Cretaceous Environments of Asia. Elsevier, Amsterdam:1-47. http://dx.doi.org/10.1016/S0920-5446(00)80023-0

Lawver, L.A., Grantz, A., Gahagan, L.M. (2002): Plate kinematic evolution of the present Arctic Region Since the Ordovician. In: E.L. Miller, A. Grantz, S.L. Klemperer (eds.), Tectonic Evolution of the Bering Shelf-Chukchi Sea-Arctic Margin and Adjacent Landmasses. Geological Society of America Special Paper 360:333-358. http://dx.doi.org/10.1130/0-8137-2360-4.333

LePain, D.L., Decker, P.L., Wartes, M.A. (2008): Measured sections and preliminary interpretations of the Nanushuk Formation exposed along the Colville River near the confluences of the Awuna and Killik Rivers. Alaska Division of Geological \& Geophysical Surveys Preliminary Information Report, 2008 1D:41-45, 197-206.

LePain, D.L., McCarthy, P.J. and Kirkham, R. (2009): Sedimentology and sequence stratigraphy of the middle Albian-Cenomanian Nanushuk Formation in outcrop, Central North Slope, Alaska: Alaska Division of Geological \& Geophysical Surveys Report of Investigation 2009-1, 78 p., 1 sheet.

Lockley, M. (1991): Tracking dinosaurs: a new look at an ancient world. Cambridge University Press, Cambridge: 238 p.

Lockley, M., Hunt, A.P. (1995): Ceratopsid Tracks and associated ichnofauna from the Laramie Formation (Upper Cretaceous: Maastrichtian) of Colorado. Journal of Vertebrate Paleontology, 15:592-614. http://dx.doi.org/10.1080/02724634.1995.100 $\underline{11251}$

Lockley, M., Meyer, C. (2000): Dinosaur tracks and other fossil footprints of Europe. Columbia University Press, New York: $323 \mathrm{p}$.

McCrea, R.T., Lockley, M.G., Meyer, C.A. (2001): Global distribution of purported Ankylosaur track occurrences. In: K. Carpenter (ed.), The Armored Dinosaurs, Indiana University Press, Bloomington:413-454.

Mull, C.G., Houseknecht, D.W., Bird, K.J. (2003): Revised Cretaceous and Tertiary Stratigraphic Nomenclature in the Colville Basin, Northern Alaska. United States Geological Survey Professional Paper 1673. Version 1.0 . http://pubs.usgs.gov/pp/ p1673/index.html.

Mull, C.G., Houseknecht, D.W., Pessel, G.H., Garrity, C.P. (2005): Geologic map of the Ikpikpuk river quadrangle, Alaska. United States Geological Survey Scientific Investigations Map 2817-B, scale $1: 250,000$.

Murie, O. (1954): A field guide to animal tracks. Houghton Mifflin Company, Boston: $374 \mathrm{p}$.

Parrish, M.J., Parrish, J.T., Hutchinson, J.H., Spicer, R.A. (1987): Late Cretaceous vertebrate fossils from the North Slope of Alaska and implications for dinosaur ecology. PALAIOS, 2:377-389. http://dx.doi.org/10.2307/3514763

Roehler, H.W., Stricker, G.D. (1984): Dinosaur and wood fossils from the Cretaceous Corwin Formation in the National Petroleum Reserve, North Slope, Alaska. Journal of the Alaska Geological Society, 4:35-41.

Russell, D.A. (1993): The role of central Asia in dinosaurian biogeography. Canadian Journal of Earth Sciences, 30:2002-2012. http://dx.doi.org/10.1139/e93-176

Sereno, P.C. (2000): The fossil record, systematics and evolution of pachycephalosaurs and ceratopsians from Asia. In: M.J. Benton, M.A. Shishkin, D.M. Unwin, E.N. Kurochkin (eds.), 
The age of dinosaurs in Russia and Mongolia. Cambridge University Press, Cambridge: 480-516.

Sues, H.-D., Averianov, A. (2009a): Turanoceratops tardabilis-first definite ceratopsid dinosaur from Asia. Naturwissenschaften, 96:645-652. http://dx.doi.org/10.1007/s00114-0090518-9

Sues, H.-D., Averianov, A. (2009b): Phylogenetic position of Turanoceratops (Dinosauria: Ceratopsia). Naturwissenschaften, 96:871-872. http://dx.doi.org/10.1007/s00114-009$\underline{0552-7}$

Wartes, M., Decker, P.L. (eds.). (2008): Preliminary results of recent geologic field investigations in the Brooks Range Foot- hills and North Slope, Alaska. Alaska Division of Geological \& Geophysical Surveys, Fairbanks Preliminary Interpretative Report 2008-1. 206 p.

Wartes, M.A., LePain, D.L., Decker, P.L. (in press): Age control, Geochemistry, and Reservoir Quality data from measured sections of the Nanushuk formation along the Colville River between the confluences with the Awuna and Killik Rivers. Alaska Division of Geological \& Geophysical Surveys Preliminary Interpretive Report.

You, H., Dodson, P. (2004): Basal Ceratopsia. In: D.B. Weishampel, P. Dodson, H. Osmólska (eds), The Dinosauria, 2nd ed. University of California Press, Berkeley:478-493. 